\title{
GEOLOGICAL CONTROL OF Podocnemis expansa AND Podocnemis unifilis NESTING AREAS IN RIO JAVAÉS, BANANAL ISLAND, BRAZIL
}

\author{
Paulo Dias FERREIRA JÚNIOR ${ }^{1} \&$ Paulo de Tarso Amorim CASTRO ${ }^{2}$
}

\begin{abstract}
The distribution of the nests of Podocnemis expansa (Amazon turtle) and Podocnemis unifilis (yellow-spotted side neck turtle) along the point bars of the Javaés River in Bananal Island, demonstrates a clear preference of these chelonians for differentiated geological environments, in respect to the morphology, grain size or height of the nests in relation to the level of the river. The topographical distribution and the differences in the grain size of the sediments that compose the point bars of the river, originated from the multiple sedimentary processes, and make possible the creation and separation of different nesting environments. Each turtle species takes advantage of the place that presents physiographic characteristics appropriate to the hatching success of their eggs. The superposition of the P. expansa and $P$. unifilis nest placement areas is rare. The P. expansa nests are concentrated on the central portion of the beaches where successive depositional sedimentary events produced sandy banks more than $3.3 \mathrm{~m}$ above the river water level. The $P$. unifilis nests are distributed preferentially in the upstream and downstream portions along the point bars where the sandy deposits rarely surpass $1.5 \mathrm{~m}$ at the moment of laying. P. expansa nests located on the beaches of fine to medium sized sand hatch in a mean of 68 days, while those incubated on beaches of medium to coarse sand size take a mean of 54 days to hatch.
\end{abstract}

Key-words: Podocnemis, turtle, sediment, nesting place, incubation duration

\section{Controle geológico das áreas de nidificação de Podocnemis expansa e Podocnemis unifilis no Rio Javaés, Ilha do Bananal, Brasil}

\begin{abstract}
RESUMO - A distribuição das covas de Podocnemis expansa (tartaruga-da-amazônia) e Podocnemis unifilis (tracajá) ao longo das barras em pontal do rio Javaés na Ilha do Bananal, mostra uma clara preferência destes quelônios por ambientes geológicos diferenciados, seja em relação à morfologia, constituição granulométrica ou altura das covas em relação ao nível do rio. A compartimentação topográfica e as diferenças no tamanho dos sedimentos que compõem as barras em pontal, oriundas de processos sedimentares múltiplos, possibilita a criação e separação de ambientes de nidificação distintos. Cada espécie de quelônio se aproveita do local que apresenta características físiográficas apropriadas à incubação de seus ovos, sendo rara a superposição das áreas de nidificação de $P$. expansa e $P$. unifilis. As covas de $P$. expansa concentram-se na porção central das praias onde sucessivos eventos de deposição produziram bancos arenosos com uma altura superior a 3,3 m em relação ao nível do rio. As covas de $P$. unifilis distribuem-se, preferencialmente, nas porções montante e jusante das barras em pontal onde os depósitos arenosos raramente ultrapassam 1,5 $\mathrm{m}$ de altura no momento da desova. Covas de $P$. expansa localizadas nas praias de areia fina a média eclodem, em média, em 68 dias ao passo que aquelas incubadas em praias de areia média a grossa levam, em média, 54 dias para eclodirem.
\end{abstract}

Palavras-chave: Podocnemis, nidificação, tartaruga, sedimento, duração da incubação

\footnotetext{
1,2 Departamento de Geologia, Escola de Minas, Universidade Federal de Ouro Preto -Campus Morro do Cruzeiro, Ouro Preto - MG (CEP: 35.400-000) -Telephone: (31) 3559-1600 -Fax (31) 3559-1605 1e-mail: pdfj@uol.com.br-2e-mail: paulo@degeo.ufop.br
} 


\section{INTRODUCTION}

The Amazon turtle (Podocnemis expansa) and the "tracajá" (yellow-spotted side neck turtle, Podocnemis unifilis) are the most common fresh water chelonians of the Tocantins-Araguaia basin. These species belong to the Pelomedusidae family, which has five species distributed throughout the northern and central western regions in Brazil (Iverson, 1992). In the Tocantins and Araguaia rivers, the Amazon turtle's and the tracajá's nesting season extends from June to December. During this period the level of the main and tributary rivers fall drastically, exposing the sandy banks which are used for nest placement. The geological aspects of these sandy banks, commonly denominated beaches, vary along the rivers being controlled by the characteristics of the substratum and hydrological regime.

The distribution of the P. expansa and $P$. unifilis nests along the sandy banks allows the characterization of environments appropriate to each of the species. In spite of the morphological differences of the sandy banks of several places, it is possible to recognize geological conditioning common to the turtle nesting areas (Ferreira Júnior 2003). In general, it is observed that the $P$. expansa prefers the central part of the beaches, where the height relative to the river water level surpasses $3.3 \mathrm{~m}$ on the date of the laying. The P. unifilis chooses upstream and downstream the areas of the beaches, where the sandy deposits usually are located $1.5 \mathrm{~m}$ above the river level, on the day of the laying. The superposition of the oviposition areas between these species is rare.

As $P$. expansa and $P$. unifilis present sexual determination dependent on the incubation temperature (Alho et al., 1985; Souza \& Vogt, 1994,;Valenzuela et al., 1997) it is important to know the nesting environment that, together with the variations of the meteorological conditions (i.e. rainfall, exposure to sunlight and the temperature of the air) will determine the temperature to which the eggs will be submitted. The hydric and thermal surroundings of the turtle nests can be influenced by several environmental and ecological factors, such as the mineralogical composition (Milton et al., 1997) and the sediments grain size (Souza
\& Vogt, 1994; Ferreira Júnior, 2003), the albedo (Hays et al., 2001), the nest depth (Burger, 1976; Wilhoft et al., 1983), the nest placement (Vogt \& Bull, 1984; Whitmore \& Dutton, 1985; Horrocks \& Scott, 1991; Hays \& Speakman, 1993), the vegetational cover (Vogt \& Bull, 1984; Janzen, 1994; Janzen \& Morjan, 2001) and the date of laying (Vogt \& Bull, 1982; Mrosovsky et al., 1984).

In this work, the geological characteristics of the $P$. expansa and $P$. unifilis nesting areas in the Javaés River, right margin of the Bananal Island in the state of Tocantins will be analyzed. From August 3 to December 15, 2000, we collected information about six beaches in which had 339 P. expansa and 487 P. unifilis nests were labeled. All of these beaches can be classified as point bars. Their sediment grain size concentrates in the sand size with very low mud content. The mineralogical composition is basically formed of quartz and feldspar.

\section{Location and physiographic aspects of the area}

The studied area is located at the margins of the Javaés River, which is the eastern border of Bananal Island, the largest fluvial island of the world. The northern part of the Bananal island forms the National Park of Araguaia, where the Center of Conservation and Management of Reptiles and Amphibians (RAN), an organ linked to the Brazilian Institute of Renewable Natural Resources (IBAMA), has a field base that supports management, research and protection activities for $P$. expansa and $P$. unifilis. (Figure 1) during the laying, incubation and hatching season.

The climatic seasonality is remarkable, with a rainy season going from September to March and a dry season from April to September. The total annual rain is around 1750 mm (IBAMA, 1995). Due to this rainfall distribution, the level of the Javaés River has extreme oscillations. During the dry season, the point bars emerge and they are used by turtles and birds (black skimmer Rynchops nigra and larged-billed tern Phaetusa simplex) as nesting sites. Rainfall close to the riverhead can cause small and fast rises ("repiquetes") in the level of the Javaés and Araguaia rivers. 


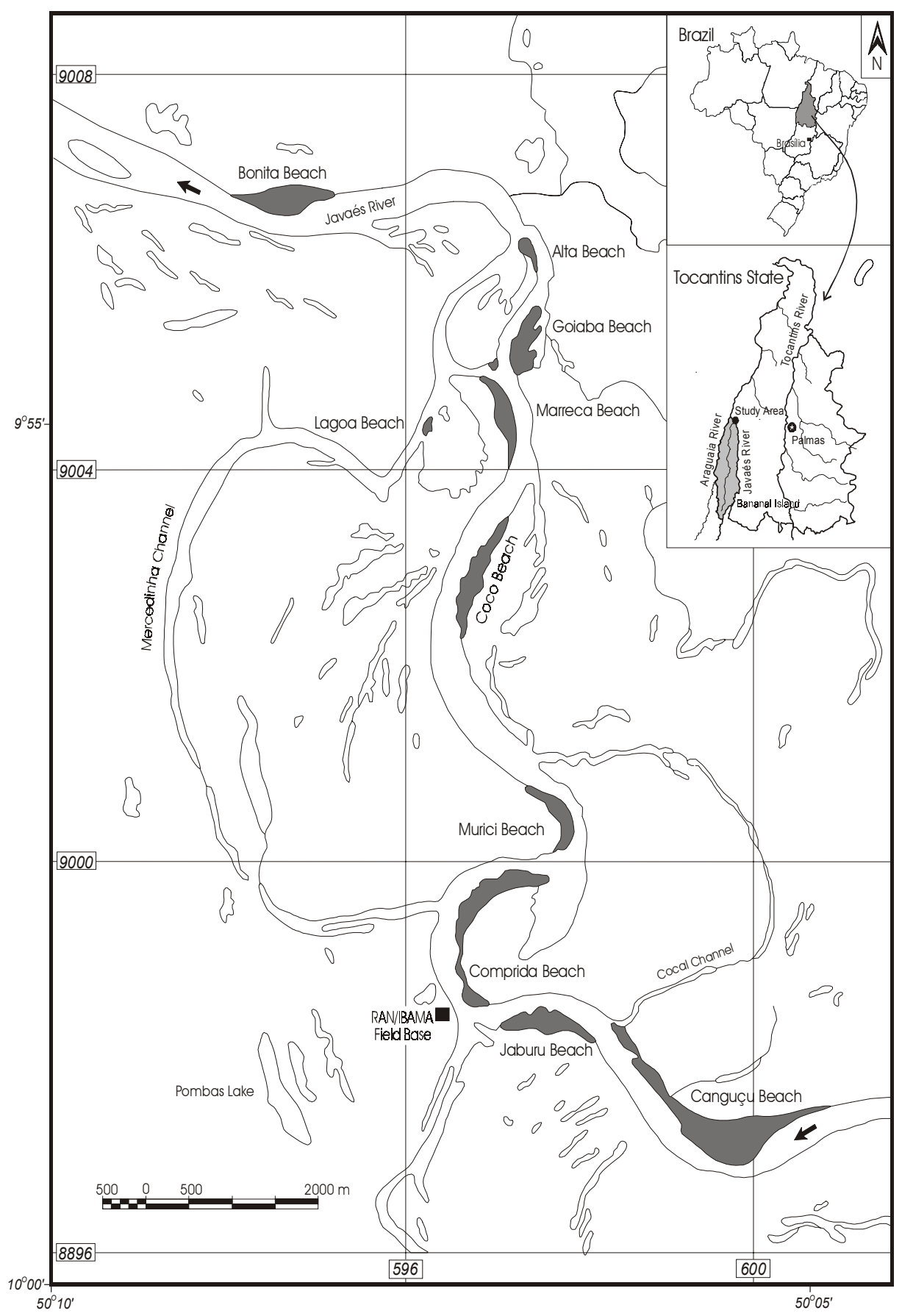

Figure 1 - Map showing the location of the studied areas. 
Because the extensive sandy banks used by the turtles are located inside the channel, there is no vegetational cover. The riparian forest that surrounds the Javaés River interferes very little in the environment of the beach. During the hottest part of the day, most of the nests receive direct sunlight. Few of them which are located at the limit of the beach and forest are shaded at the end of the afternoon.

\section{MATERIALS AND METHODS}

Six beaches have been chosen, namely Canguçu, Jaburu, Comprida, Marreca, Coco and Murici are located close to the RAN/ IBAMA field base. These beaches have the largest concentration of $P$. expansa and P. unifilis nests in the Araguaia National Park. Searching for nests is done by members of the research teams and by the agents of IBAMA. Every morning the beaches are spanned, looking for tracks left by the turtles in previous night. The tracks are followed until the nests are located and labeled with numbered sticks.

During the monitoring of the laying season, it was decided not to label the nests of $P$. unifilis in the Marreca and Murici beaches. Both of them have fine sand and it is hard to locate nests there, since wind action frequently obscures the turtle tracks. However, the Jaburu and Comprida beaches that are also formed by fine sand were monitored because they are located close to the IBAMA field base. In this case, the travel time to the beaches is so short to permit the observation of some $P$. unifilis tracks before the wind obliterates them.
The mapping of the beaches was done on a scale of 1:1000 using theodolite, compass and tape measure. This scale allowed the representation of the main beach morphology and channel features, as well as the plotting of all the turtle nests. The mapping was accomplished in the month of October, when the oviposition had been finished, in order not to interfere in the laying process. The height of the nests was measured with the aid of a Kern level with a precision of $5 \mathrm{~mm}$. The measurements were made in order to define two height types:

The height on the laying date, which reflects the topographical conditions found by the turtles during the oviposition.

The maximum height of the nests, aiming the establishment of a common pattern among the several beaches, with respect to the topographical conditions.

The maximum height of the nests was registered on November $1^{\text {st }}$, when the Javaés River reached its lowest depth. On this day, the Javaés River depth was taken and it allowed comparisons among the heights of the nests in all the beaches. The level of the Javaés River was taken daily close to the IBAMA base from August to December, during the nest monitoring period.

As the beaches are composed of sediments, generally poorly selected and disposed in layers, samples were collected close to the material that recovers the nests and which was homogenized during the closing of the nests by the turtle females. Three hundred and twelve samples of sediments were submitted to the granular analysis according to the scale of Folk/ Wentworth (Table 1).

Table 1 - Granulometric fractions used in the analyses of 312 samples of sediments collected in the nests of $P$. expansa and $P$. unifilis. Dimensions are given in $\mathrm{mm}$.

\begin{tabular}{cccccccccc}
\hline \multirow{2}{*}{ Fraction } & \multirow{2}{*}{ Pebble } & Gravel & \multicolumn{5}{c}{ Sand } \\
\cline { 4 - 9 } & & & Very coarse & Coarse & Medium & Fine & Very fine & Mud \\
\hline Dimension & $>4$ & $4-2$ & $2-1$ & $1-0.5$ & $0.5-0.25$ & $0.25-0.125$ & $0.125-0.065$ & $<0.065$ \\
\hline
\end{tabular}

Student's t-test was used in the analysis of the variations of the height, incubation duration and depth of the nests between $P$. expansa and P. unifilis. Variance analysis (ANOVA) has been used for determination of the variations of the incubation duration along the beaches. Linear regression has been used in the determination of the grain size influence of the sediments on the incubation duration. All statistical analysis was performed according to Zar (1998). Significance has been accepted at a level of $5 \%$. The data of the mean will be presented followed \pm SD (standard deviation). 
Figure 2 gives the terminology of the beaches used in this work. Here geomorphologic and topographic criteria were used. The length of the point bars is measured in its largest extension, parallel to the channel.
The width of the point bars is the maximum width taken perpendicularly to the channel. The analysis of the height of the dunes follows the recommendations of Ashley (1990) (Table 2).

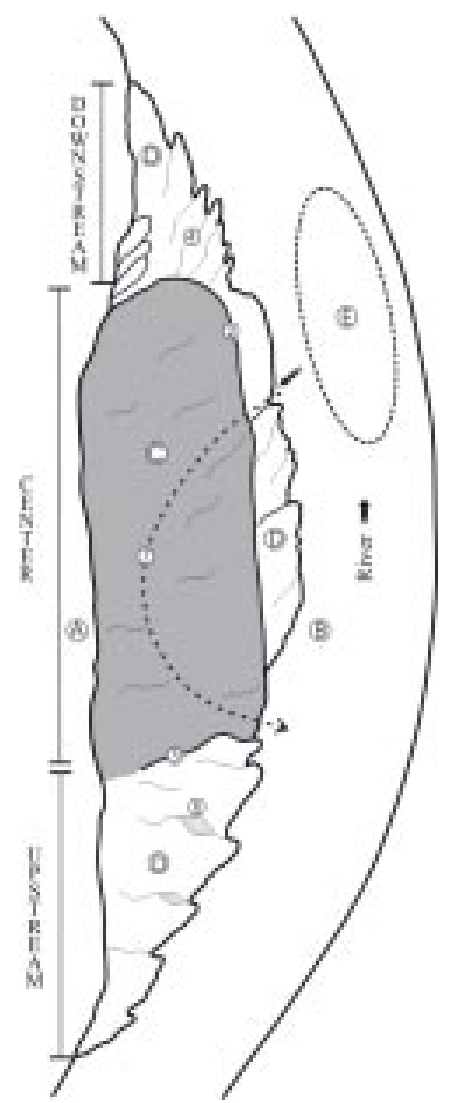

Figure 2 - Terminology used and features collected in mapping of the Javaés River point bars. A: Margin or internal part of the point bar, close to the forest. B: External margin of the point bar in contact with the river. C: The hatched part indicates the high beach points, generated by the migration and amalgamation of several sandy deposits. There are dunes of small and medium size. The main nesting is by $P$. expansa. D: Low part of the beach with heights under 1.5 $\mathrm{m}$ and normally used as nesting site by the P. unifilis. E: "Boiadouro", representing the deepest points of the rivers where the turtles float and wait for the adequate moment to exit for the nesting. 1: Channel chute bars - sandy deposits with a lobete form. They generally develop in the downstream portion of the point bar and they constitute one of the highest sites of the beach. They are used as nesting sites by P. expansa. 2: Abrupt front part constituted by the amalgamation of several large-sized dunes. This feature is named accretionary dune front by Ashworth et al. (2000). It divides the beach in two distinct topographical regions. 3: Crest of a large-sized dune. 4: Crest of a small and medium sized-dune. 5: Temporary ponds generated in front of the dunes. 6: Trough located in front of the large-sized dunes that connect the deepest points of the river to the nesting sites. They are used as access way by $P$. expansa. 7: Path covered by $P$. expansa during the nesting. 
Table 2 - Classification of the dimensions of the dunes, recommended by Ashley (1990) and used in this work. The spacing is measured between the crests of the dunes.

\begin{tabular}{lccccc}
\hline & \multicolumn{5}{c}{ Dunes (2D e 3D) } \\
\hline Dimension $(\mathrm{m})$ & Ripple & Small & Medium & Large & Very large \\
Spacing & $<0.6-5$ & $0.6-5$ & $5-10$ & $10-100$ & $>100$ \\
Height & $<0.075-0.4$ & $0.075-0.4$ & $0.4-0.75$ & $0.75-5$ & $>5$ \\
\hline
\end{tabular}

\section{RESULTS}

All the beaches that were studied in the Javaés River can be classified as point bars that, according to Levey (1978) are sediments deposited along the internal part of the meander occupying the area of the channel between the thalweg and the inferior limit of the floodplain. The dimensions of the point bars depend on their positioning, with the dimensions on the left margin being smaller than those on the right margin (Table 3). The height of the nests of $P$. expansa approximately indicates the height of the beaches. According to the average values it can be observed that, in the place chosen for nesting by $P$. expansa, the beaches of the left margin are higher than the ones of the right margin (Table 4).

Table 3 - Dimensions of the point bars of the Javaés River used for nesting by P. expansa in the studied area. The length of the point bar is measured in its largest extension, parallel to the channel, and the width is taken in the maximum point perpendicularly to the channel (see Figure 2). The width refers to the extreme point of the beach

\begin{tabular}{lcc}
\hline Beach & Length $(\mathrm{m})$ & Width $(\mathrm{m})$ \\
\hline Right margin & & 470 \\
Canguçu & 2970 & 250 \\
Comprida & 2350 & 260 \\
Coco & 3450 & \\
Left margin & & 190 \\
Jaburu & 1160 & 160 \\
Murici & 820 & 165 \\
Marreca & 800 & \\
\hline
\end{tabular}

Table 4 - Mean \pm SD of the maximum height of the nests of $P$. expansa and $P$. unifilis along the point bars of the Javaés River in 2000 . The date of November $1^{\text {st }}$ was taken as reference, because it was when the Javaés River reached its lowest depth. The nests of $P$. unifilis were not marked in Marreca and Murici beaches. The numbers between parentheses are the sample size.

\begin{tabular}{|c|c|c|c|c|}
\hline \multirow[b]{2}{*}{ Beach } & \multicolumn{2}{|c|}{ Podocnemis expansa } & \multicolumn{2}{|c|}{ Podocnemis unifilis } \\
\hline & Maximum height $(\mathrm{cm})$ & Range & Maximum height $(\mathrm{cm})$ & Range \\
\hline Canguçu & $313.0 \pm 58.17(50)$ & $117-427$ & $182.2 \pm 78.05(133)$ & $66-472$ \\
\hline Comprida & $363.6 \pm 63.79(16)$ & $267-526$ & $197.1 \pm 92.77(53)$ & $55-410$ \\
\hline Murici & $539.1 \pm 58.45(23)$ & $243-471$ & & \\
\hline Coco & $296.4 \pm 51.02(163)$ & $102-448$ & $107.7 \pm 32.71(180)$ & $45-375$ \\
\hline All the beaches & $332.4 \pm 88.48(278)$ & $102-646$ & $148.4 \pm 75.65(403)$ & $33-472$ \\
\hline
\end{tabular}

There is a minimum required height for the nesting (Figure 3a). Each species chooses an area with a suitable height range relative to the level of the Javaés River in the date of the laying $(\mathrm{t}=25.74, \mathrm{df}=520, \mathrm{p}<0.001)$. The data suggest that $50 \%$ of the nests of $P$. expansa are between 250 and $329 \mathrm{~cm}$ high at the date of the laying. This condition excludes the areas upstream, downstream and close to the margin of the river. The P. unifilis behavior is different and the height of $50 \%$ of the nests varies from 48 to $126 \mathrm{~cm}$ at the 
date of the laying. This situation is found upstream and downstream parts of the beaches and also in the external portions of the point bars.

The depth of the nests varies between the species $(\mathrm{t}=77.13$, df $=483, \mathrm{p}<$ $0.001)$. The nests of $P$. unifilis being shallower $(\mathrm{x}=15.6 \pm 1.95 \mathrm{~cm}, \mathrm{n}=207)$ than the ones of $P$. expansa $(\mathrm{x}=60.4 \pm 8.17 \mathrm{~cm}, \mathrm{n}=$ 278) (Figure $3 b$ ).

The incubation duration - considered here as the period between the laying and the hatchling emergence from the nest - varies significantly among the species $(\mathrm{t}=25.19, \quad \mathrm{df}=331, \mathrm{p}<0.001)$ (Figure 3c).
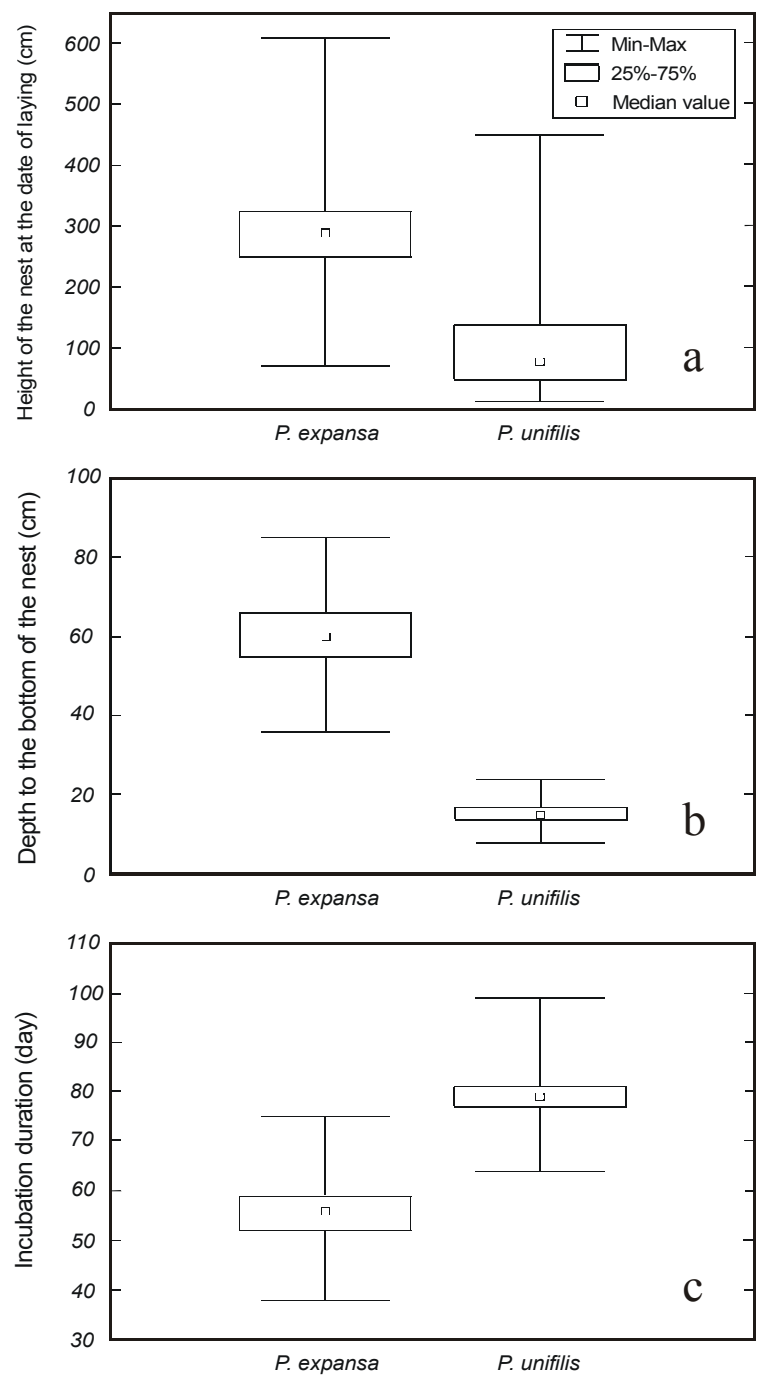

Figure 3 - Reproductive and biological parameters of $P$. expansa and $P$. unifilis in the nesting season of 2000 in the Javaés River. a) Height of the nests of $P$. expansa and $P$. unifilis in the date of laying. Sample size: 278 P. expansa nests and 244 P. unifilis nests. b) Depth of $P$. expansa and $P$. unifilis nests. Sample size: 278 P. expansa nests and 207 P. unifilis nests. c) Incubation duration of $P$. expansa and $P$. unifilis nests. Sample size: 271 P. expansa nests and 62 P. unifilis nests. 
For $P$. expansa there is an outstanding difference between the incubation duration along the beaches $\left(\mathrm{F}_{5,265}=26.94, \mathrm{p}<\right.$ 0.001 ) (Table 5, Figure 4a). The beaches of fine to medium sand size like Jaburu, Comprida, Marreca and Murici present an average incubation duration of $63.5 \pm 7.38$ days, while in those of medium to coarse sand such as Canguçu and Coco the incubation duration is of $54.4 \pm 5.05$ days.

The incubation duration of $P$. unifilis does not vary significantly along the beaches $\left(\mathrm{F}_{3,58}=0.92, \mathrm{p}=0,4351\right)$ and it has an average of $79.8 \pm 6.43$ days (Table 6 , Figure 6).
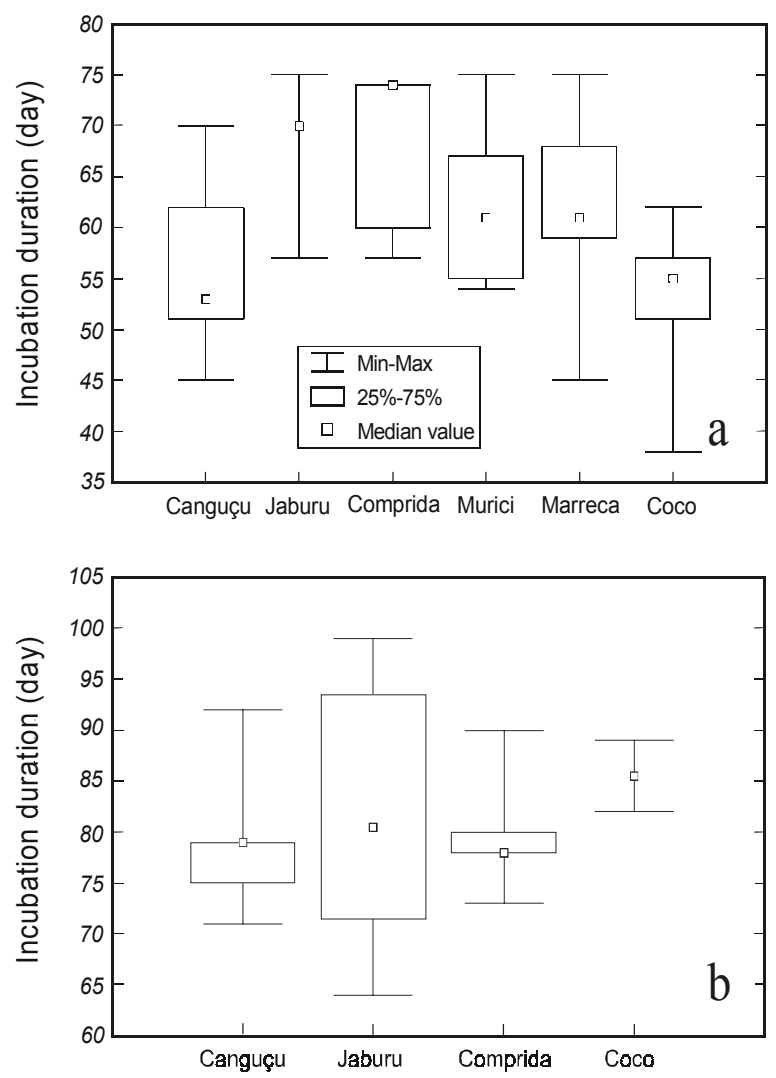

Figure 4 - Incubation duration along the beaches of Javaés River during the nesting season of 2000. a) P. expansa, b) P. unifilis.

Possible sources of influence on the incubation duration show significant differences between the species. The nest grain size $\left(\mathrm{F}_{5,265}=9.05, \mathrm{R}^{2}=0.2009, \mathrm{p}<0.001\right)$ and the nests height, in the date of the laying $\left(\mathrm{F}_{1,238}=84,10, \mathrm{R}^{2}=0.2611, \mathrm{p}<0.001\right)$, as well as the maximum height registered in November $1^{\text {st }}\left(\mathrm{F}_{1.238}=103.82, \mathrm{R}^{2}=0.2755\right.$, $\mathrm{p}<0.001)$, affected the incubation duration of $P$. expansa. They did not show an influence on $P$. unifilis incubation time (Table 6). The depth of the nest affects the incubation duration of $P$. unifilis $\left(\mathrm{F}_{1.54}=5.30, \mathrm{R}^{2}=0.0895\right.$, $\mathrm{p}=0.0251)$ and it does not interfere in $P$. expansa $\left(\mathrm{F}_{1.257}=0.89, \mathrm{R}^{2}=0.0025, \mathrm{p}=\right.$ $0.3451)$. 
Table 5 - Mean \pm SD of the incubation duration of $P$. expansa and $P$. unifilis along the beaches in the nesting season of 2000 . The incubation duration is the period that goes from the laying to the hatchling emergence, and it is given in days. The numbers between parentheses are the sample size.

\begin{tabular}{lcccc}
\hline \multirow{2}{*}{ Beach } & \multicolumn{2}{c}{ Podocnemis expansa } & \multicolumn{2}{c}{ Podocnemis unifilis } \\
\cline { 2 - 5 } Canguçu & $54.9 \pm 6.04(55)$ & $45-70$ & $78.7 \pm 4.88(38)$ & $71-92$ \\
Jaburu & $65.0 \pm 7.56(6)$ & $57-75$ & $80.9 \pm 9.98(14)$ & $64-99$ \\
Comprida & $66.3 \pm 6.94(17)$ & $55-74$ & $80.7 \pm 4.95(30)$ & $73-89$ \\
Murici & $61.6 \pm 6.96(30)$ & $54-75$ & & Range \\
Marreca & $62.4 \pm 6.59(20)$ & $45-75$ & & $70-89$ \\
Coco & $54.2 \pm 4.49(186)$ & $36-62$ & $80.0 \pm 4.65(38)$ & $64-99$ \\
Medium to fine sand beaches* & $63.2 \pm 7.03(73)$ & $45-75$ & $80.9 \pm 4.65(34)$ & $70-92$ \\
Coarse to medium sand beaches** & $54.4 \pm 4.90(241)$ & $38-70$ & $79.5 \pm 4.85(76)$ & $64-99$ \\
All the beaches & $56.4 \pm 6.59(314)$ & $38-75$ & $79.8 \pm 5.63(120)$ & Incubation duration (days) \\
\hline
\end{tabular}

*The beaches of finer to medium sand compose Murici, Marreca, Jaburu and Comprida beaches.

** The beaches with medium to coarse sand compose Coco and Canguçu beaches.

Table 6 - Linear regression analysis of variables that can affect the incubation duration of $P$. expansa and $P$. unifilis. The grain size refers to the granulometric fractions of medium and fine sand.

\begin{tabular}{lccccccccc}
\hline & \multicolumn{4}{c}{ P. expansa } & \multicolumn{4}{c}{ P. unifilis } \\
\cline { 2 - 10 } & $\mathrm{df}$ & $\mathrm{R}^{2}$ & $\mathrm{~F}$ & $\mathrm{p}$ & $\mathrm{df}$ & $\mathrm{R}^{2}$ & $\mathrm{~F}$ & $\mathrm{p}$ \\
\hline Grain size & 2,217 & 0.2785 & 41.89 & $<0.001$ & 2,87 & 0.0043 & 0.1916 & 0.8259 \\
Nest depth & 1,264 & 0.002 & 0.6631 & 0.4161 & 1,54 & 0.0895 & 5.30 & 0.0251 \\
Height of the nest at the date of laying & 1,273 & 0.2539 & 92.91 & $<0.001$ & 1,113 & 0.0052 & 0.59 & 0.4421 \\
Maximum height of the nest & 1,273 & 0.2755 & 103.82 & $<0.001$ & 1,113 & 0.0169 & 1.95 & 0.1652 \\
\hline
\end{tabular}

It was possible to delineate two groups of beaches with different characteristics from the grain size analysis of samples collected in the nests of $P$. expansa (221 samples) and $P$. unifilis (92 samples). The Jaburu, Marreca, Murici, and Comprida beaches present finer sediments, well selected and concentrated in the fine and medium sand fractions. The other group is formed by Canguçu and Coco beaches where the sediments are coarse, poorly selected, and they are distributed in the very coarse, coarse, medium, and fine sand fractions (Table 7). The content of mud in all the six beaches is small and restricted to temporary ponds at the trough of the dunes. The maximum volume of clay registered was $6.08 \%$, the mean being $0.12 \% \pm 0.38$.
Data on the monitoring provided by IBAMA show the distribution of the nests of $P$. expansa since the implementation of the project in 1990. The $P$. expansa usually chose the beaches of the right margin (Figure 5).

The point bars differ not only for their dimensions and grain size, but each margin presents its own geological characteristics. The point bars of the left margin are shorter and higher than those of the right margin (Tables 3 and 4). In general, the grain size of the sediments that compose the beaches of the right margin is coarse than those of the left margin. The other geological parameters, mainly those related to the morphology of the beaches are not measurable, will be described in detail. 
Table 7 - Average grain size constitution of the nests of $P$. expansa and P. unifilis in the Javaés River in the nesting season of 2000.

\begin{tabular}{|c|c|c|c|c|c|c|c|c|c|}
\hline \multirow[b]{2}{*}{ Beach } & \multirow[b]{2}{*}{ Sample size } & \multirow[b]{2}{*}{ Pebble } & \multirow[b]{2}{*}{ Gravel } & \multicolumn{6}{|c|}{ Sand } \\
\hline & & & & Very coarse & Coarse & Medium & Fine & Very fine & Mud \\
\hline \multicolumn{10}{|l|}{ Canguçu } \\
\hline All nests & 64 & 0.23 & 1.14 & 4.92 & 25.47 & 48.01 & 18.36 & 1.49 & 0.25 \\
\hline P. expansa & 36 & 0.23 & 1.58 & 6.34 & 30.87 & 44.76 & 14.21 & 1.72 & 0.26 \\
\hline P. unifilis & 28 & 0.22 & 0.83 & 3.09 & 18.53 & 52.19 & 23.68 & 1.21 & 0.23 \\
\hline \multicolumn{10}{|l|}{ Jaburu } \\
\hline All nests & 12 & 0.79 & 1.88 & 4.05 & 20.47 & 48.21 & 22.39 & 2.01 & 0.19 \\
\hline P. expansa & 2 & 0 & 0 & 0.08 & 2.59 & 43.47 & 52.47 & 1.31 & 0.07 \\
\hline P. unifilis & 10 & 0.94 & 2.27 & 4.84 & 24.05 & 49.15 & 16.38 & 2.15 & 0.21 \\
\hline \multicolumn{10}{|l|}{ Comprida } \\
\hline All nests & 30 & 0.18 & 0.87 & 2.73 & 15.44 & 41.37 & 36.05 & 3.16 & 0.20 \\
\hline P. expansa & 9 & 0 & 0.17 & 0.68 & 6.56 & 35.51 & 53.98 & 2.95 & 0.14 \\
\hline P. unifilis & 21 & 0.26 & 1.17 & 3.61 & 1.25 & 43.88 & 28.36 & 3.24 & 0.21 \\
\hline \multicolumn{10}{|l|}{ Coco } \\
\hline All nests & 184 & 0.64 & 2.27 & 8.62 & 28.79 & 38.95 & 19.63 & 1.02 & 0.07 \\
\hline P. expansa & 152 & 0.61 & 2.37 & 9.46 & 31.07 & 37.79 & 17.79 & 0.85 & 0.04 \\
\hline P. unifilis & 32 & 0.75 & 1.84 & 4.64 & 17.92 & 44.47 & 28.32 & 1.85 & 0.21 \\
\hline \multicolumn{10}{|l|}{ Murici } \\
\hline P. expansa & 15 & 0 & 0.01 & 0.13 & 4.41 & 56.48 & 37.55 & 1.39 & 0.03 \\
\hline \multicolumn{10}{|l|}{ Marreca } \\
\hline P. expansa & 7 & 0.08 & 0.08 & 0.52 & 7.41 & 74.61 & 16.55 & 0.70 & 0.05 \\
\hline
\end{tabular}

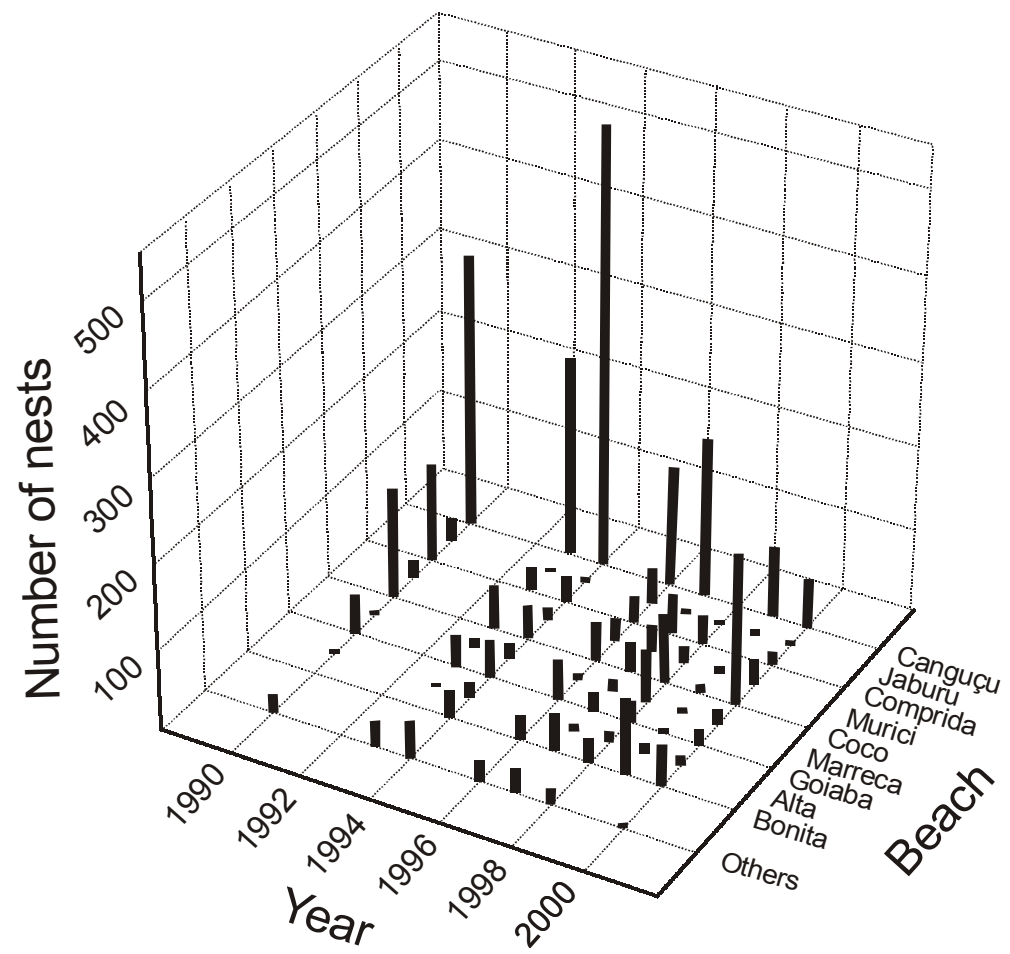

Figure 5 - Number of P. expansa nests per year of each studied beach from 1999 to 2001. 


\section{Beaches of the left margin}

\section{Jaburu Beach}

The Jaburu beach historically presents the smallest number of nesting of $P$. expansa (Figure 5); in 2000 only eight nests were registered. The $P$. expansa chooses the highest points in the center of the beach close to the internal limit of the point bars (Figure 6). The highest nest is placed on a channel chute bar in the downstream portion of the beach.

The nests of $P$. unifilis are predominantly found in the upstream and downstream parts of the Jaburu beach. The nests are located mainly close to the base of the dunes. On the nesting date the nests are usually located in sand lower than $1.5 \mathrm{~m}$ in height $(\mathrm{x}=$ $132 \pm 100.2 \mathrm{~cm})$. In the center of the beach, close to the external margin (close to the water line), the nests of $P$. unifilis are located where the height is lower.

\section{Marreca Beach}

Channel chute bars with its typical lobed geometry occur in the downstream portion of the Jaburu and Marreca beaches. The subsequent part of these bars has bushes, which helps its fixation. Marreca beach (Figure 7), like the other point bars of the Javaés River, has its downstream internal limit formed by a scarp which is formed by erosion due to secondary channels flow during the flood period. Inside these channels the chute bars are develop. It is common to find nests of $P$. expansa in the top of the chute bars that frequently constitute the highest portion of the point bars. In the Marreca beach four nests of $P$. expansa were found in the top of the chute bars while in the Jaburu beach only two nests were found.

\section{Murici Beach}

Murici beach has a concentration of 26 nests in a small area of about 1 ha (Figure 8). The upstream and downstream portion of the Murici beach and the places close to the exter- nal margin are avoided by the $P$. expansa, because the height in these places is very low, under $1.5 \mathrm{~m}$.

Murici beach presents a pattern of distribution of chelonian nests similar to Jaburu and Marreca beaches. There is a continuous increase in the height of the beach towards the center portion of the point bar in a "slope" pattern.

In Jaburu, Marreca and Murici beaches the exit of the $P$. expansa happens always in specific points in the troughs of the dunes, which act as a connection between the deepest parts of the river and the beaches. The path followed by the turtles, marked by their tracks, describes a path upstream as well as downstream, with no apparent preferential direction. P. expansa tracks are not found on the abrupt margins of the beach, where the declivity is high.

\section{Beaches of the right margin}

\section{Canguçu Beach}

Canguçu beach marks the upstream limit where the nesting of $P$. expansa in significant numbers. Above this beach the Javaés River becomes shallower, frequently less than $30 \mathrm{~cm}$ deep, and the beaches become lower with rare high elevations points. This fact preclude $P$. expansa nestsing. On the other hand, the P. unifilis is common upstream Canguçu beach, in spite of being not as abundant as in the study area.

When the water level of the Javaés River lowered during the dry season extensive sandy banks in the center portion of Canguçu beach emerged. These deposits subdivide the "boiadouro" (popular denomination of the deepest points of the rivers where the chelonian await for the adequate moment to exit for the nesting - Figure 2) in two parts. These parts are linked by a narrow channel. $P$. expansa emerge from "boiadouro" through this channel to the beach. P. expansa do not nest on the part of the beach in front of the sandbanks portion near the "boiadouro". 
Devavtream the brwer part of the pein bor. it is firmol by imall deres will cress in bigh ancle wia respoct to lavads Viver drectarn in

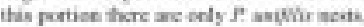

Chamel chale bar, it is the higher part of fie back suacties $444 \mathrm{~cm}$ bigh.

Center: the area clese wo the cainernal narga kexpe a

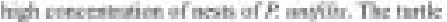

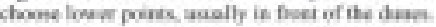

The higher pent of this derrain is in the mental narzin

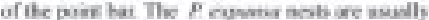
lincasod tere. Whe prosernt the danes is this and ate aracod at large inkrvah.

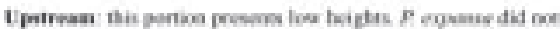
moten ia this placx.

\section{Legend}

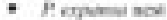

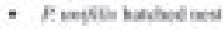

- Prabsed $P$ inxmir exar

Con eflares vise dase

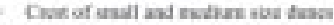

Fahower by fo nowa herre the neating Daske
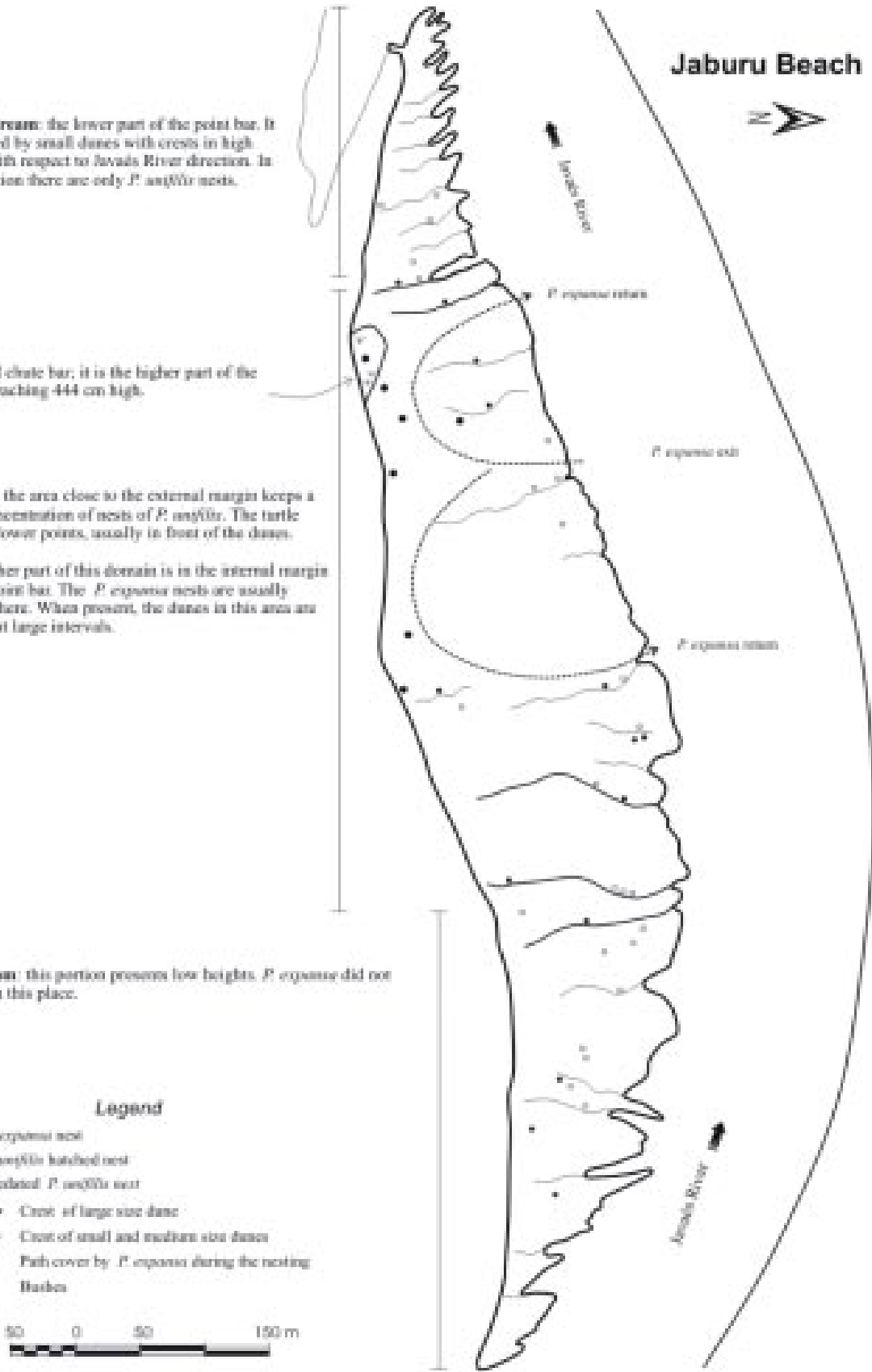

Figure 6 - Distribution of $P$. expansa and P. unifilis nests along the Jaburu Beach. 
Downstream: low part of the point bar constituted of small dunes oriented in high angle with respect to Javaés River direction.

Channel chute bar: deposits generated in the period of flooding. They are formed by a topographical hight that are used as nesting place by some $P$. expansa.

Front part of a large dune that limits the high part of the beach. Nests of $P$. expansa are frequent.

Center: high part of the point bar. Nests of $P$. expansa spread on this area. There is not a specific point that concentrates some of 17 nests.

In the external part of the beach there are small and spaced dunes. The internal part is plain without dunes. To the internal portion a fast increase of the height of the beach takes place.

Upstream: small and spaced dunes. Since the dune are spaced there is no sufficient increase of the height in order to permit the nesting of $P$. expansa. Only nests of $P$. unifilis are found at this place.

\section{Legend}

- P. expansa nest
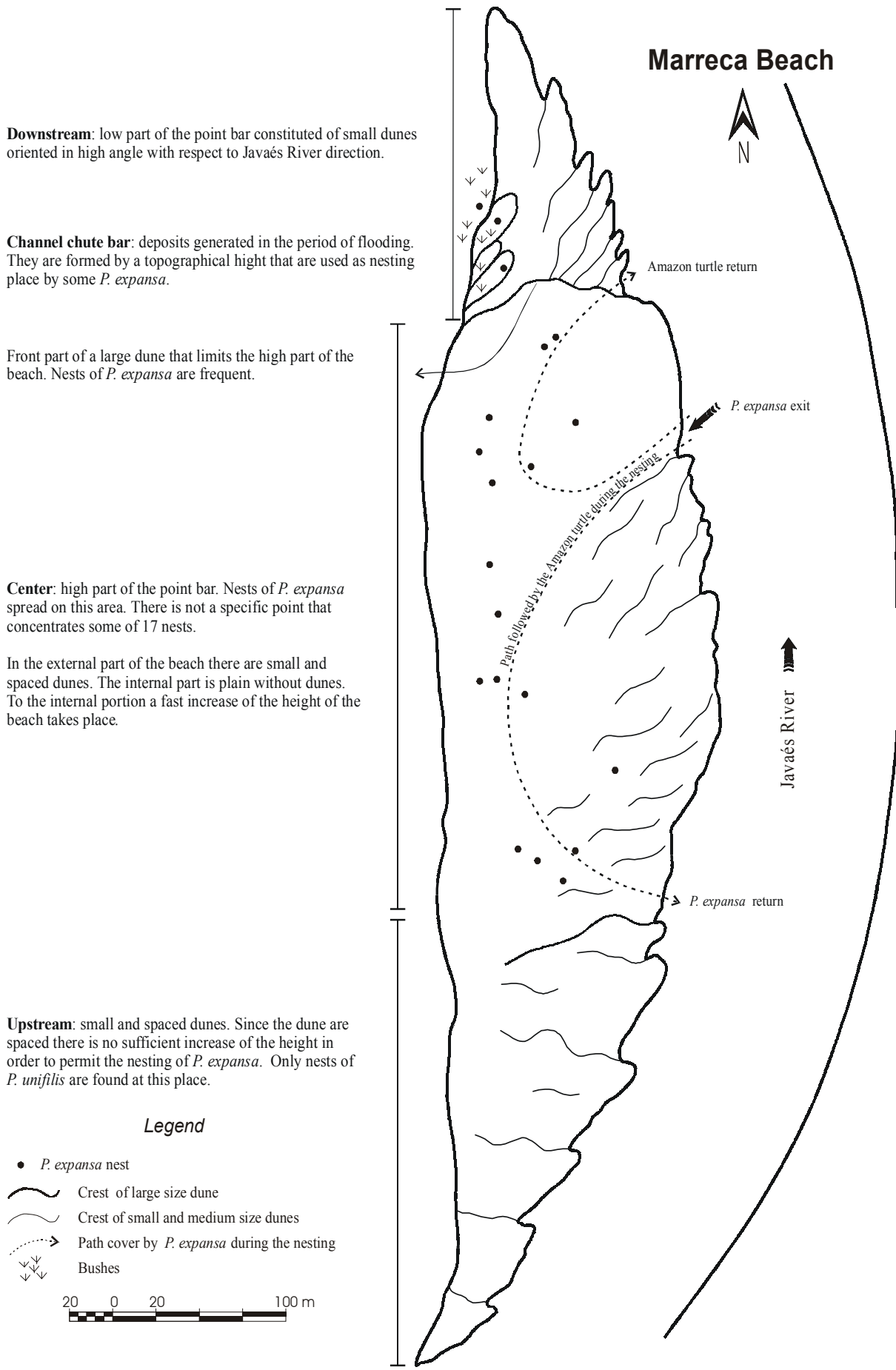

Figure 7 - Distribution of $P$. expansa nests along the Marreca Beach. 
Downstream: small dunes that migrate orientated with high angle with respect to the Javaés River direction.

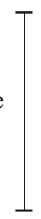

Center: accretionary dune front marks the boundary between center and downstream portion. Its position near a large and deep trough turn the clibing of the $P$. expansa to the highest point possible.

Area with high concentration of $P$. expansa nests. The place chosen for the nesting is relatively plain.

At this area is plain and the nests are more spreadout.

In the external part, there are dunes of small and medium sizes that migrate with crests oriented with high angle with respect to the Javaés River direction.

The nests are dispersed in a large and relatively plain area in the stoss side of the large-sized dunes that are set at large intervals.

\section{更}

\section{Murici Beach}

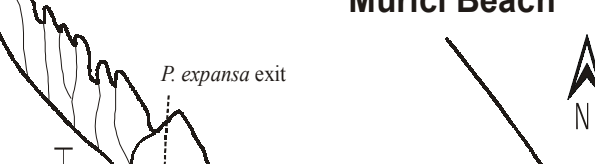

$A$

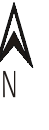


Canguçu beach can be divided in two parts (Figure 9). a) Upstream - it is formed by an extensive area characterized by the curved line of the point bar. The accretionary dune front is oriented at a low angle in respect to the channel direction. It is separated from the downstream part by a topographical high area which had 23 nests of $P$. expansa, along 32 ha. During the dry season, erosive processes occur in the upstream portion of the beach where the curvature of the channel is more pronounced. As a result of the erosive processes a $1 \mathrm{~m}$ high scarp at the external margin of the beach is formed. This scarp acts as a barrier for the $P$. expansa and $P$. unifilis to exit from water to beach in this area. b) Downstream - there is a narrow, long part of the beach, without pronounced topographical high, where the dunes crests is in high angle with respect to the channel direction. The height of the beach increases slowly and gradually towards the internal part of the point bar. The arrangement of the dunes in high angle favors the development of several access channels in their trough. The nesting of $P$. expansa take place in the internal margin of the beach close to the forest. Cocal channel has the largest number of nests of $P$. expansa. It has water only during the high water season, when the Javaés River winds its way through its extensive floodplain and creates alternative paths for water flow (Figure 1). In this place of about 4 ha, 33 nests of $P$. expansa were found. The nests of $P$. unifilis are distributed throughout the nesting area and concentrate close to the base of the dunes.

\section{Comprida Beach}

It can be divided in two parts, due to the complexity of the deposits and the concentration of the nests. A narrow sandy strip, up to $10 \mathrm{~m}$ wide and $250 \mathrm{~m}$ long, makes the connection between the upstream and downstream domains, submerged after the beginning of November (Figure 10). a) Upstream - it is marked by channel chute bars that apparently have been deposited through the interaction of the flow of the Javaés and Riozinho rivers. Shrub growth stabilizes the sand deposits of the channel chute bars. There were four $P$. expansa nests and only one $P$. unifilis nest found in this habitat. b) Downstream - it is a shelf formed by the migration and overposition of several dunes with crests in a high angle with respect to the channel direction. It is a well marked topographical unevenness. In this place, in 1999, a large nesting of $P$. expansa was registered, with about 120 nests. At the end of the point bar there are several channel chute bars that are responsible for the largest heights registered on the beach.

The $P$. expansa took advantage of the countless existing access channels in the trough of the dunes in order to reach the beach. Fiftyfive nests of $P$. unifilis are distributed in the upstream part of this domain, where the height of the point bar is up to $2 \mathrm{~m}$ high. The nests concentrate mainly at the base of the dunes. The access to the nesting place is done, frequently, from the channels located in the trough of these dunes. There is not a specific point through which a great number of turtles ascend to the beach.

\section{Coco Beach}

It is a large point bar developed in a meander on the right margin of the Javaés River (Table 3). It had the largest number of $P$. expansa and $P$. unifilis nests in 2000 (Figure 11). The upstream portion shows evidence of recent deposition, emerging for the first time in 2000. The amalgamation of the deposits is not verified and as a consequence, the height of the nests of $P$. unifilis registered is below 46 $\pm 5.94 \mathrm{~cm}$ at the time of the laying $(\mathrm{n}=22)$ and $108 \pm 8.52 \mathrm{~cm}$ in November $1^{\text {st }}$, when the Javaés River was at its smallest level. Most of the nests of $P$. unifilis are located on crest of the dunes in this area. There are nests close to the base of the dunes, and not just on the crest of the dunes in places where the height of the beach is higher.

The downstream part is plain, including dunes of small size spaced in a high angle with respect to the direction of the river. Since amalgamation of the deposits generated by the migration of the dunes does not happen, the heights are modest. In this case there is only one $P$. unifilis nest. In November the rising of the Javaés River caused the fast inundation of almost all the nesting area. 


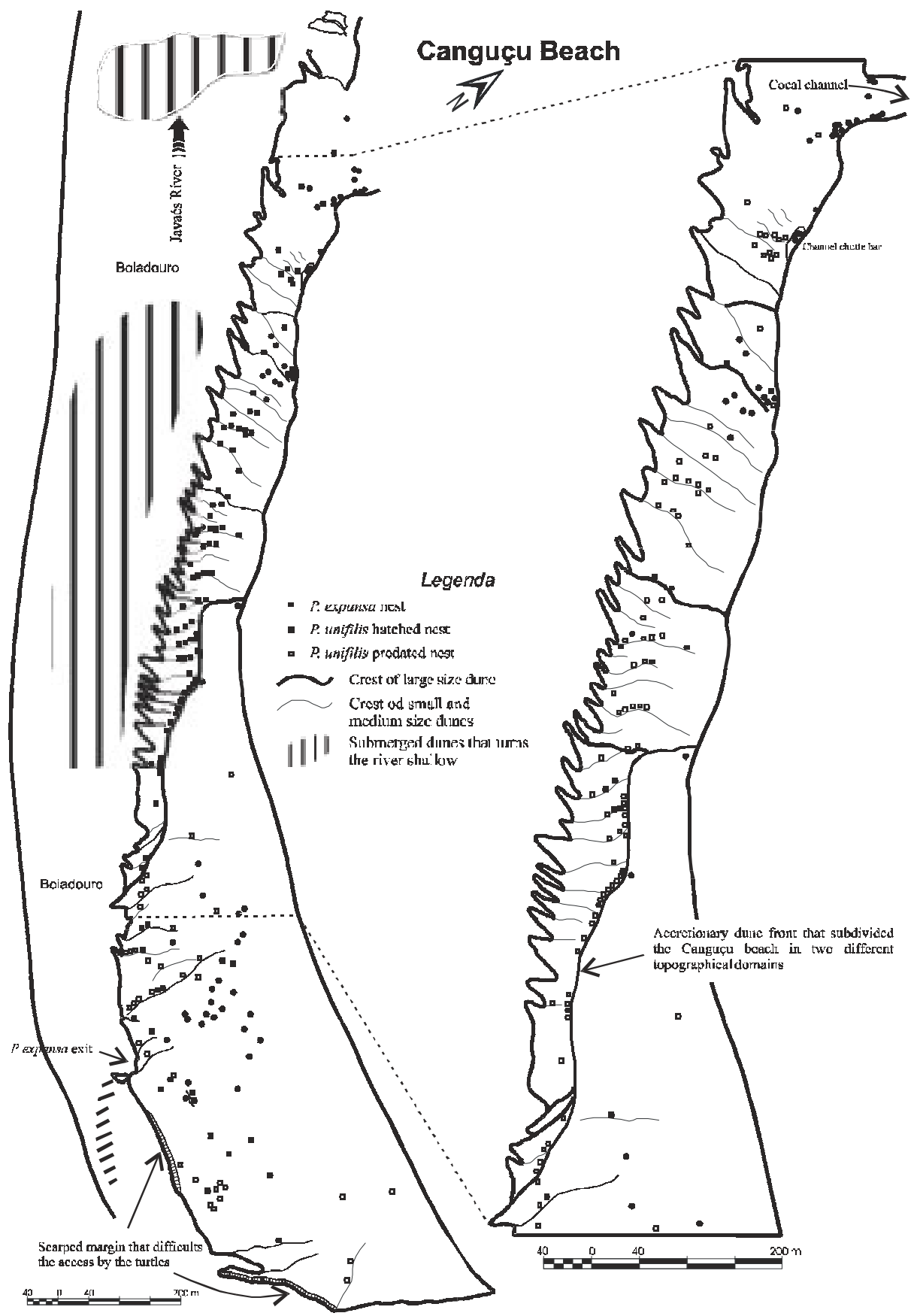

Figure 9 - Distribution of P. expansa and P. unifilis nests along the Canguçu Beach. 


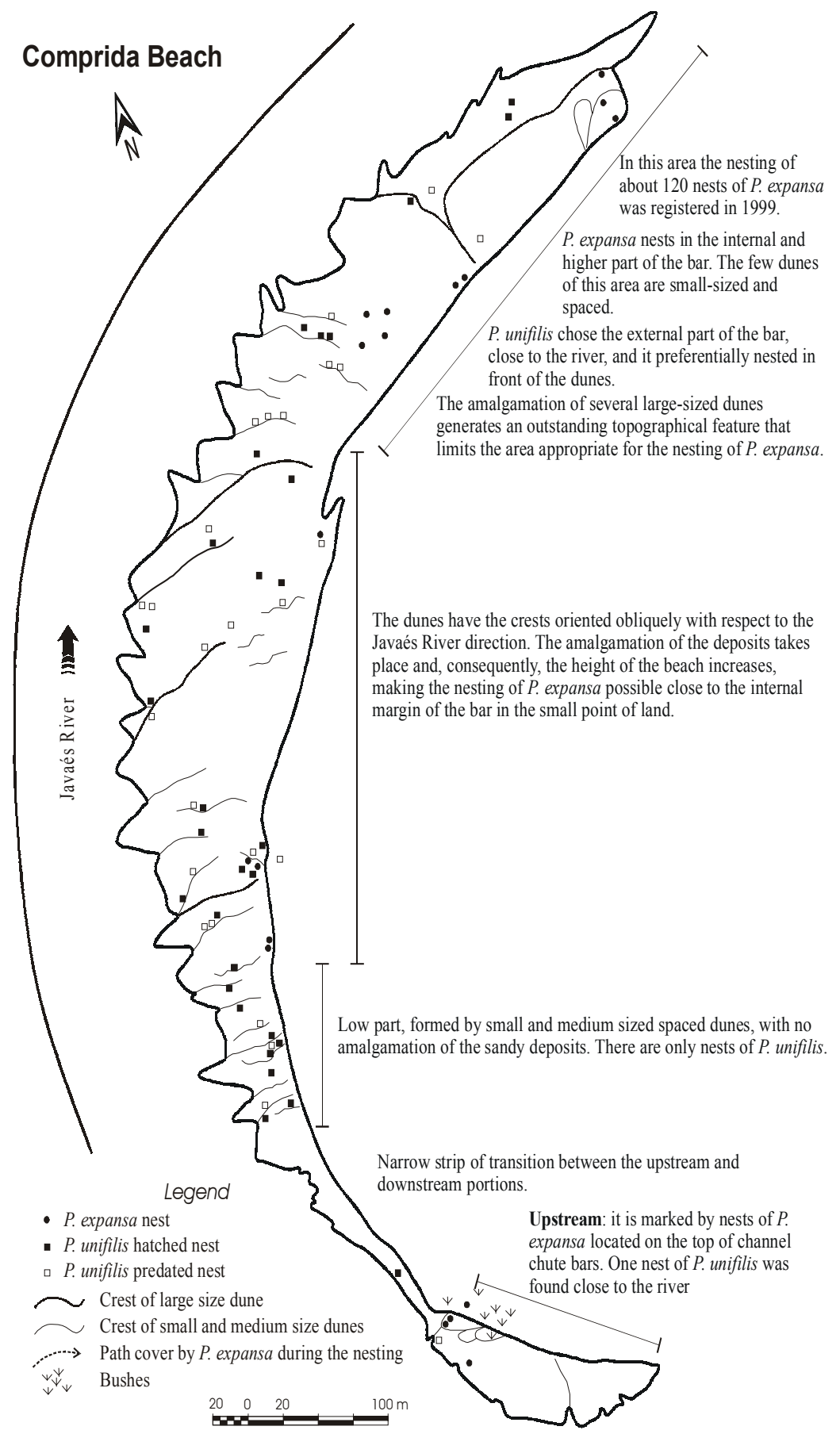

Figure 10 - Distribution of $P$. expansa and P. unifilis nests along the Comprida Beach. 


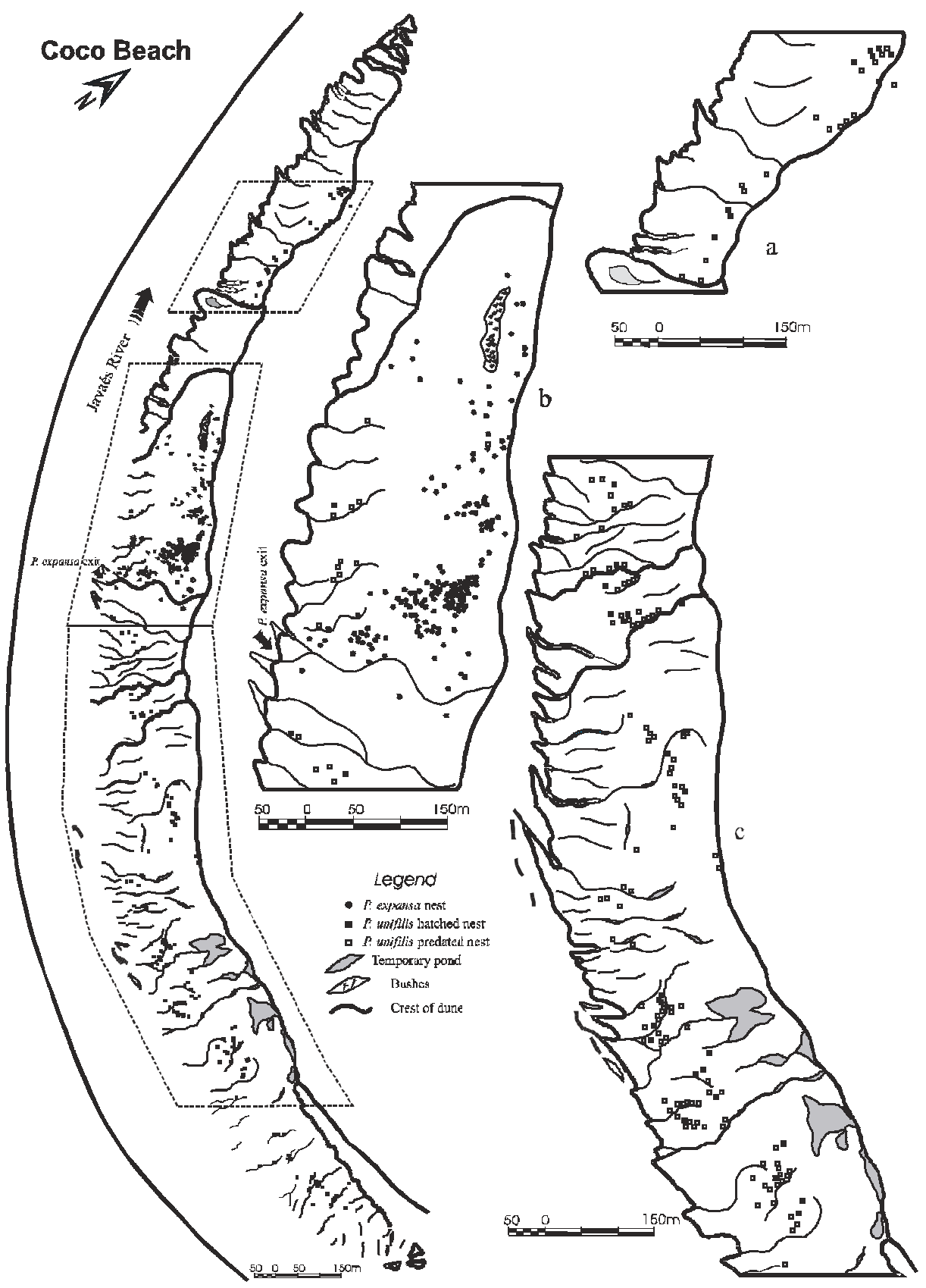

Figure 11 - Distribution of $P$. expansa and P. unifilis nests along the Coco Beach. a) downstream, b) center, c) upstream. 
In the central part, where the largest number of nesting of $P$. expansa happened, the height of the beach increases gradually downstream, without significant steeps. The dunes are of medium to large size, spaced, with crests at a high angle with respect to the channel direction, and frequently they cross the beach entirely. The spacing between the dunes is reduced in the downstream direction and they start to migrate one over the other, amalgamating and increasing the height of the point bar. A small-vegetated area serves as an obstacle to the migration of the dunes in the middle of the beach. The beach is flat in this area. The end of the area of nesting of $P$. expansa is marked by an accretionary dune front, about $200 \mathrm{~cm}$ high. The amalgamation of the deposits has created a great elevation in this area, whose crest is almost parallel to the direction of the channel.

The location of the tracks of $P$. expansa indicates that exist is at specific point, close to the trough of a great dune. The path of the turtles had a paraboloid shape not only upstream but downstream as well. The return did not occur in a specific point of the channel. The concentration of exits of the turtle at a given point can be explained based in the morphology of the beach and in the existing relationships between the sandy deposits and the "boiadouro". Sandy upstream bars, although immersed to small depths, made the locomotion of $P$. expansa difficult. The points that allow the connection between the "boiadouro" and the beach are restricted and concentrated in the trough of the dunes, way ahead of the highest parts of the point bar.

\section{DISCUSSION}

Temperature-dependent sex determination in most species of turtle studied raised attention to the conditions that govern or interact with the substratum, determining the temperature which the eggs undergo during the embryogenesis. According to Charnov \& Bull (1977), Bull (1980), Bulmer \& Bull (1982), and Janzen \& Morjan (2001) the sex ratio of the offspring is governed by two factors: a) thermal sensitivity of the embryo to the sexual determination, b) maternal choice of the thermal qualities of the nesting place. Janzen \& Morjan (2001) showed that Chrysemys picta use the same microenvironment in successive nesting, which is in agreement the theory that the females can "control" the sex ratio of the offspring by the choice of the thermal environmental of the nests.

Several examples show the importance of the nesting place in the survival and in the embryonic development of several lizard species and turtles. In all cases it seems clear that the choice of the nesting places is not random and seeks to match the physiologic characteristics of the adult females (i.e. size and terrestrial locomotion agility) and characteristics of the clutches (i.e. clutch size) to the characteristics of the environment (hydric and thermal) that will control the embryogenesis.

For Ewert et al. (1994) the pivotal temperature will have a decisive influence on the place chosen for the nesting of four fresh water species in a same region. Therefore the sex ratio of the offspring stays balanced, since the females use places with different thermal characteristics. This would compensate the differences of the pivotal temperature among the species.

Burger (1976) has observed that the temperature of the nests of Malaclemys terrapin terrapin depends on the position of the nest on a sandy dune. Hays et al. (2001) had attributed the thermal variations in the several environments of the beaches to the albedo difference. Bodie (2001), in a compilation work, pointed out that most of the species of fresh water turtle prefer open and sandy beaches for the nesting and that they can seek alternative habitats, such as levees, when their traditional nesting places are not available. Raising of the river could put the eggs at risk, as pointed by Alho \& Pádua (1982), for P. expansa and by Standing et al. (1999), for Emydoidea blandingi.

Souza \& Vogt (1994), while analyzing P. unifilis in Costa Marques (RO), had indicated that nests located in sunny places and in sediments in the coarse size sands (1 to $0.5 \mathrm{~mm}$, according to these authors' classification) experiment larger daily temperature fluctuation. The average temperature of the nests located in sediments in the coarse size sand is larger 
than that of the nests in fine sand. These authors did not associate the sex ratio of the offspring with the grain size of the substratum; they just suggested that the nests located in coarse sediments would bias female sex ratio more than those placed in finer sediments.

The grain size of the substratum where the nests are placed does not have influence only on the temperature. For the sea turtle Chelonia mydas to makes a nest cavity it is necessary that the place presents humidity or small roots that give enough cohesion to the substratum in order to prevent the walls from tumbling (Bustard \& Greenham, 1968). Chelonia mydas constructs a nest more easily in finer sand (Mortimer \& Carr, 1987). The coarse and dry sand makes the opening of the nests difficult, forcing the females to dig several places before finding an appropriate local.

Hatchling success is influenced strongly by the nest site for fresh water turtle species as P. expansa (Alho \& Pádua, 1982; Ferreira Júnior 2003), Emys orbicularis (Servan et al., 1989), E. blandingii (Standing et al., 1999), and sea turtle species such as Dermochelys coriacea (Whitmore \& Dutton, 1985), Eretmochelys imbricata (Horrocks \& Scott, 1991) and Caretta caretta (Hays \& Speakman, 1993). Beaches with different hatchling success present larger concentration of nests in the points where the survival of the offspring is larger (Horrocks \& Scott, 1991; Hays \& Speakman, 1993).

Bragg et al. (2000) compared the nesting locals of different lizards, and the species with temperature-dependent sex determination on the (Eublepharis macularius and Hemitheconyx caudicinctus) preferred places with intermediate temperatures. On the other hand, the species Coleonyx mitratus, which possesses genetic sexual determination, did not have a preferred place.

In the Javaés River the nesting areas of $P$. expansa and P. unifilis show different morphologic aspects. Although both species can use the same point bar each species chooses morphologically different places to nest. The mineralogical constitution is relatively homogeneous in all the six beaches and it does not influence the nest site chosen by individuals of either the both species, nor does it affect duration incubation.
The data suggest that the grain size distribution in and among different beaches affects significantly the incubation duration of $P$. expansa. The $P$. expansa is selective in the choice of the nesting places, preferring historically the beaches constituted by coarse sediments. Since 1990 (Figure 5) the largest concentrations of nests always took place in the point bars of the right margin. Besides the larger complexity of the beaches, the grain size sediments of the right margin are coarse. This fact indicate a primary control of the geological aspects on the reproductive biology of $P$. expansa.

The incubation duration varies significantly among the beaches for $P$. expansa due in part to the influenced of grain size of the sediments (Table 6 and Figure 4a). There are differences of incubation duration between the Coco beach, with a mean of $54.2 \pm 4.48$ days, and Comprida beach, with a mean of $68.3 \pm$ 7.70 days. The longer incubation duration for Comprida beach is associated to its finer grain size sediments. Grain size of the sediments influences on the incubation time for P. expansa, but not for $P$. unifilis (Table 6). Other elements should be interacting and affecting the embryogenesis of $P$. unifilis.

It is worth highlighting two characteristics that are different for the two species studied: the height of the nests and the eggshell type. In accordance with Pritchard \& Trebbau (1984) the eggshell of $P$. expansa is flexible and the one of $P$. unifilis is rigid. For Packard et al. (1982) eggs with flexible eggshells are more sensitive to the variations of the hydric environment, absorbing water in humid conditions and becoming dehydrated in dry ones. The water exchange with the environment is related to the metabolic rate, affecting the incubation duration. Eggs with rigid eggshells, as $P$. unifilis, present low porosity and little exchange of water with the environment, being less dependent from the hydric environment. Thus, it seems that for $P$. unifilis the rate of embryonic development and the incubation duration are not affected by the hydric conditions of the nests.

The difference in the constitution of the eggshells of the P. expansa and P. unifilis eggs (Pritchard \& Trebbau, 1984) helps to under- 
stand the differences found in the microenvironment in the nests. The rigid eggshell of $P$. unifilis makes possible incubation at smaller depths. Perhaps, this would be possible even in drier places, because the dehydration of the eggs is minimized by the small porosity of the eggshell (Packard et al., 1982). On the other hand the eggs of $P$. expansa demand a greater depth (Figure $3 b$ ), since the eggshell does not supply an adequate protection against the dehydration.

The height and the depth of the nests of $P$. unifilis and $P$. expansa should also affect the microenvironment of the nests (Figure 3a and $3 \mathrm{~b}$ ). The $P$. expansa nests are deeper than the $P$. unifilis nests (Figure $3 \mathrm{~b}$ ), which in part, control the distribution of the nests along the beaches. Wilson (1998) suggests that medium and large sized turtles, such as $P$. expansa (Alho et al., 1985) and Apalone mutica (Plummer et al. 1994), nesting in open areas to maximize the exhibition of the nests to the sun, and small turtles as Kinosternon baurii need the protection of the vegetation and of the humidity since they can not dig deep nests and avoid very high temperatures. Shallow nests are submitted to large daily oscillations of temperature (Burger, 1976; Thompson, 1988; Wilson, 1998). The lower depth of the water table and the stemming increase of humidity could minimize the daily variations of the temperature. The greater humidity would minimize the influence of the heat exchange, which is more effective in coarse and dry sediments than in fine and humid sediments (Harrison, 1985; Novak \& Black, 1985; Harrison \& Morrison, 1993).

The bottom of the clutch of $P$. expansa is located at an mean depth of $61 \mathrm{~cm}$ (Figure $3 b)$. Algo in oceanic beaches there are not significant differences of the sand temperature at a depth of $60 \mathrm{~cm}$ (Mrosovsky et al., 1984). In spite of the difference between the sea and fluvial environments, it is believed that the profile of heat transmission in large depths has a similar behavior, with daily variations of temperature being small at such depths. A greater height of the beach is required so that the humidity originated from the water table is in a range appropriate to the incubation.

Another fact that can be related to the greater height required by the eggs is the syn- chronism between the drought of the river and the nesting behavior of $P$. expansa. The beginning of the nesting season is associated with the stabilization of the river in its lowest level (Alho \& Pádua, 1982). The survivorship of late hatching of some clutches would be influenced if the rise of the river water level were anticipated. In this case, higher areas nesting position allows the hatching of most of the nests, even if the level of the river rises faster ("repiquetes"). The eggs of $P$. unifilis, in the 2000 nesting season, begin hatching in the second half of October, before water level began to rise.

The choice of the nest sites is related to some habitat requirements, such as, the presence of "boiadouros", access channels and topographical levels. The morphology of the beach will bring direct consequences to the distribution of the nests. Wide and relatively plain and uniform areas such as the central part of the Marreca beach (Figure 7) and the upstream part of the Canguçu beach present nests of $P$. expansa uniformly distributed. The appropriate height for $P$. expansa is only reached when the river water flow makes successive events of migration of the dunes and amalgamation of the dunes. The choice of the central part of the beaches of the right margin (Figure 9 and 11) explains this aspect. The separation among the high areas, chosen by $P$. expansa and the low parts, selected by $P$. unifilis in Coco, Canguçu, Comprida and Murici beaches is clear.

The dimensions and morphology of the point bars will depend on their positioning and interaction with the water flow of the channel. In spite of being smaller, the point bars of the left margin are higher and its external margins are more abrupt, which sometimes hinders the access of the females to the nesting places. A great elevation of a place alone is not enough to define the best area for nesting of $P$. expansa (Tables 3 and 4). In spite of the smaller heights, the beaches of the right margin are, historically, the most used by P. expansa (Figure 1 and 5).

The Javaés River is deep and calm enough to allow the turtles to rest in the vicinity of the beaches. The Canguçu beach clearly exemplifies the importance of the "boiadouros". The greater concentration of nests in 1990, 1993, 1994, 1996, 1997 (Figure 
5) happened at the Canguçu beach. Nowadays, the Canguçu beach importance has been reduced in comparison to Coco and Comprida beaches. Reports of the field agents that work in the project since its implantation in 1990 describe the decrease of the "boiadouro" as a result of the formation of sandy banks that, even when submerged, make the navigation in the area difficult. The smaller nesting of $P$. expansa in Canguçu beach is partially attributed to the decrease of the "boiadouro" area.

The nesting decrease of $P$. expansa in Comprida beach in 2000 is not well understood, since the "boiadouro" is still deep and there is easy access to the beach without the presence of sandy banks to difficult the turtles exit. The beach height remained similar up until last year. The decrease of more than 120 nests, in 1999 , to only 18 nests in 2000 , will only be explained with the monitoring for couples of years more.

Due to its smaller size and larger mobility, $P$. unifilis reach the beaches more easily, frequently using the channels in the trough of small dunes, which are common along the upstream and downstream parts of the point bars (Figures 9, 10 and 11). Channels of access that exist in the trough of the dunes make the connection of the "boiadouro" to the highest points of the beach. Its importance can be verified at Coco beach, where the exit of $P$. expansa is concentrated at one only point. This fact helps to understand the high nesting rate in that portion of the point bar. In the other beaches, where there are several access channels or the morphology of the beach is a ramp-like, there was not a high concentration of nests at only one point. The exit of $P$. expansa happens in only one point of in the upstream portion of Canguçu beach close to a submerged sandy bank that marks the upstream limit of the "boiadouro".

Souza \& Vogt (1994) attribute the differentiation of the nesting areas of these species in the beaches, to the fact that the destruction of the nests of $P$. unifilis by $P$. expansa that nested later. This hypothesis is rejected for the beaches monitored in the Javaés River, because besides being very wide, there is not a superposition of the nesting areas. The distribution of the nests of $P$. expansa and $P$. unifilis shows the influence of the fluvial environment on the choice of the nesting area. This distribution in separated morphological places should be considered in the management projects that frequently use to transfer of nests. As we could observe, it is not only sufficient to transfer the nests to high places, above the earlier rise of the level of the rivers ("repiquetes") because at least for the $P$. unifilis, proximity with the water table is required by the turtles at the moment of the nesting. If we change the environmental conditions (which means change in thermal and hydric conditions), we can somehow induce unforeseen or poorly understood modifications on the reproductive biology of turtles.

\section{ACKNOWLEDGMENTS}

This work is part of the $\mathrm{PhD}$ research of Paulo Dias Ferreira Júnior accomplished in the Departamento de Geologia of the Universidade Federal de Ouro Preto, with a scholarship by CAPES. The support in the field work was given by RAN/IBAMA and by the Instituto Ecológica. We would like to thank Divaldo Rezende and Mariluce Messias of the Instituto Ecológica and Antônia Lúcia and Yeda Bataus of RAN/IBAMA. Special thanks to Adriana Malvasio from Universidade Federal do Tocantins for critical reading of the manuscript and presentation to the world of turtles. We thank Paulo de Marco Júnior from Universidade Federal de Viçosa for the help in the statistical analysis. The collection of the data was only possible with the help of the of RAN/IBAMA agents, Gonzaga and Alfreu and the undergraduate students of the Universidade Federal do Tocantins, Giovanni, Eliene, Odimar, Fernando, Jackson, Edileila, Marcos, Valderico, and undergraduate students of the Universidade Federal de Ouro Preto, Ariadne and Luís Gustavo. Our thanks to the friends Marcos and Rossana for the hospitable welcome at the Centro de Pesquisas Canguçu.

\section{LITERATURE CITED}

Alho, C.J.R.; Pádua, L.F.M. 1982. Reproductive parameters and nesting behaviour of the Amazon turtle Podocnemis expansa 
(Testudinata: Pelomedusidae) in Brazil. Canadian Journal of Zoology, 60(1): 97-103.

Alho, C.J.R.; Danni, T.M.S.; Pádua, L.F.M. 1985. Temperature-dependent sex determination in Podocnemis expansa (Testudinata: Pelomedusidae). Biotropica, 17(1): 75-78.

Ashley, G.M. 1990 Classification of large-scale subaqueous bedforms: a new look at an old problem. Journal of Sedimentary Petrology, 60(1): 160-172.

Ashworth, P.J.; Best, J.L.; Roden, J.E.; Bristow, C.S.; Klaassen, G.J. 2000 Morphological evolution and dynamics of a large, sand braid-bar, Jamuna River, Bangladesh. Sedimentology, 47(3): 533-555.

Bodie, J.R. 2001. Stream and riparian management for freshwater turtles. Journal of Environmental Management, 62: 443-455.

Bragg, W.K.; Fawcett, J.D.; Bragg, T.B. 2000. Nest-site selection in two eublepharid gecko species with temperature-dependent sex determination and one with genotypic sex determination. Biological Journal of the Linnean Society, 69: 319-332.

Bull, J.J. 1980. Sex determination in reptiles. The Quarterly Review of Biology, 53(1): 320.

Bulmer, M.G.; Bull, J.J. 1982. Models of polygenic sex determining and sex ratio control. Evolution, 36(1): 13-26.

Burger, J. 1976. Temperature relationships in nests of the northern diamondback terrapin, Malaclemys terrapin terrapin. Herpetologica, 32(4):412-418.

Bustard, H.R.; Greenham, P. 1968. Physical and chemical factors affecting hatchling in the green sea turtle, Chelonia mydas (L.). Ecology, 49(2):269-276.

Charnov, E.L.; Bull, J.J. 1977. When is sex environmentally determined. Nature, 266(5605): 828-830.

Ewert, M.A.; Jackson, D.R.; Nelson, C. E. 1994. Patterns of temperature-dependent sex determination in turtles. The Journal of Experimental Zoology, 270(1): 3-15.
Ferreira Júnior, P.D. 2003. Influência dos processos sedimentológicos e geomorfológicos na escolha das áreas de nidificação de Podocnemis expansa (tartaruga-da-amazônia) e Podocnemis unifilis (tracajá) na bacia do rio Araguaia. Tese de Doutorado, Departamento de Geologia, Universidade Federal de Ouro Preto, Ouro Preto, Minas Gerais. 296p.

Harrison, S.J. 1985. Heat Exchanges in muddy intertidal sediments: Chichester Harbour, West Sussex, England. Estuarine, Coastal and Shelf Science, 20: 477-490.

Harrison, S.J.; Morrison, P. 1993. Temperatures in a sandy beach under strong solar heating: Patara Beach, Turkey. Estuarine, Coastal and Shelf Science, 37(1): 89-97.

Hays, G.C.; Speakman, J.R. 1993. Nest placement by loggerhead turtles, Caretta caretta. Animal Behaviour, 45(1): 47-53.

Hays, G.C.; Ashworth, J.S.; Barnsley, M.J.; Broderick, A.C.; Emery, D.R.; Godley, B.J.; Henwood, A.; Jones, E.L. 2001. The importance of sand albedo for the thermal conditions on sea turtle nesting beaches. Oikos, 93(1): 87-94.

Horrocks, J.A.; Scott, N.M. 1991. Nest site location and nest success in the hawksbill turtle Eretmochelys imbricata in Barbados, West Indies. Marine Ecology Progress Series, 69(1): 1-8.

IBAMA - Instituto Brasileiro do Meio Ambiente e dos Recursos Naturais Renováveis 1995. Plano de Ação Emergencial para o Parque Nacional do Araguaia. IBAMA, Brasília. 104p.

Iverson, J.B. 1992. A Revised Checklist with Distribution Maps of the Turtles of the Word. Indiana. Earlham College, Richmond. 363p.

Janzen, F.J. 1994. Vegetational cover predicts the sex ratio of hatchling turtles in natural nests. Ecology, 75(6): 1593-1599.

Janzen, F.J.; Morjan, C.L. 2001. Repeatability of microenvironment-specific nesting behaviour in a turtle with environmental sex determination. Animal Behaviour, 62(1): 73-82. 
Levey, R.A. 1978. Bed-form distribution and internal stratification of coarse-grained point bars upper Congaree River, S.C. In: Miall, A. (Ed.) Fluvial Sedimentology, Memoir 5. Canadian Society of Petroleum Geologists, Calgary. p.105-127.

Milton, S.L.; Schulman, A.A.; Lutz, P.L. 1997. The effect of beach nourishment with aragonite versus silicate sand on beach temperature and loggerhead sea turtle nesting success. Journal of Coastal Research, 13(3): 904-915.

Mortimer, J.A.; Carr, A. 1987. Reproduction and migrations of Ascension Island green turtle (Chelonia mydas). Copeia, 1987(1): 103-113.

Mrosovsky, N., Dutton, P.H., Whitmore, C.P. 1984. Sex ratio of two species of sea turtle nesting in Suriname. Canadian Journal of Zoology, 62(11): 2227-2239.

Novak, M.D.; Black, T.A., 1985. Theoretical determination of the surface energy balance and thermal regimes of bare soils. Boundary Layer Meteorology, 33: 313333.

Packard, M.J.; Packard, G.C.; Boardman, T.J. 1982. Structure of eggshells and water relations of reptilian eggs. Herpetologica, 38(1): 136-155.

Plummer, M.V.; Shadrix, C.E.; Cox, R.C. 1994. Thermal limits of incubation in embryos of softshell turtles (Apalone mutica). Chelonian Conservation and Biology, 1(2): 141-144

Pritchard, P.C.H.; Trebbau, P. 1984. The Turtles of Venezuela. Society for the Study of Amphibians and Reptiles, Caracas. 403p.

Servan, J.; Zaborski, P.; Dorrizi, M.; Pieau, C. 1989. Female-biased sex ratio in adults of the Emys orbicularis at the northern limit of its distribution in France: a probable consequence of interaction of temperature with genotype sex determination. Canadian Journal of Zoology, 67(5): 1279-1284.
Souza, R.R.; Vogt, R.C. 1994. Incubation temperature influences sex and hatchling size in the neotropical turtle Podocnemis unifilis. Journal of Herpetology, 28(4): 453-464.

Standing, K.L.; Herman, T.B.; Morrison, I.P. 1999. Nesting ecology of Blanding's turtle (Emydoidea blandingii) in Nova Scotia, the northeastern limit of the species' range. Canadian Journal of Zoology, 77(10): 1609-1614.

Thompson, M.B. 1988. Nest temperatures in the Pleurodian Turtle, Emydura macquarii. Copeia, 1988(4): 996-1000

Valenzuela, N.; Botero, R.; Martínez, E. 1997. Field study of sex determination in Podocnemis expansa from Colombian Amazonia. Herpetologica, 53(3): 390-395.

Vogt, R.C.; Bull, J. 1982. Temperature controlled sex-determination in turtles: ecological and behavioral aspects. Herpetologica, 38(1): 156-164.

Vogt, R.C.; Bull, J. 1984. Ecology of hatchling sex ratio in map turtle. Ecology, 65(2): 582-587.

Whitmore, C.P.; Dutton, P.H. 1985. Infertility, embryonic mortality and nest-site selection in leatherback and green sea turtles in Suriname. Biological Conservation, 34(3): 251-272.

Wilhoft, D.C.; Hotaling, E.; Franks, P. 1983. Effects of temperature on sex determination in embryos of the snapping turtles, Chelydra serpentina. Journal of Herpetology, 17(1): 38-42.

Wilson, D.S. 1998. Nest-site selection: microhabitat variation and its effects on the survival of turtle embryos. Journal of Herpetology, 22(1): 88-96.

Zar, J.H. 1998. Biostatistical Analysis. Prentice Hall, New Jersey. 929p.

\section{Recebido: 13/08/2002}

\section{Aceito: 20/03/2003}

